\title{
Distribution of alien species along sand dune plant communities zonation
}

\author{
DANIJELA STEŠEVIĆ \\ MILICA LUKOVIĆ2 \\ DANKA CAKOVIĆ ${ }^{3}$ \\ NEMANJA RUŽIĆ 4 \\ NADA BUBANJA ${ }^{5}$ \\ URBAN ŠILC 6,7
}

1 University of Montenegro, Faculty of Natural Sciences and Mathematics, Biology department, Džordža Vašingtona bb, 81000 Podgorica, Montenegro (danijela.stesevic@ac.me)

2 University of Kragujevac, Faculty of Hotel Management and Tourism, Department of Natural Science, Vojvodjanska bb, 36210 Vrnjačka Banja, Serbia (mpetrovic.azs@gmail.com)

${ }^{3}$ University of Montenegro, Faculty of Natural Sciences and Mathematics, Biology department, Džordža Vašingtona bb, 81000 Podgorica, Montenegro (danka.petrovic@t-com.me)

${ }^{4}$ University of Montenegro, Faculty of Natural Sciences and Mathematics, Biology department, Džordža Vašingtona bb, 81000 Podgorica, Montenegro (nemanja.sharpe@gmail.com)

${ }^{5}$ Natural History Museum of Montenegro, Trg vojvode Bećir-bega Osmanagića 16, 81000 Podgorica, Montenegro (nadabubanja@t-com.me)

${ }^{6}$ ZRC SAZU (Research Centre of the Slovenian Academy of Sciences and Arts), Institute of Biology, Novi trg 2, 1000 Ljubljana,

Slovenia (urban@zrc-sazu.si)

BC Naklo, Strahinj 99, 4202 Naklo, Slovenia

\section{Correspondence:}

Urban Šilc

E-mail: urban@zrc-sazu.si

Key words: Psammophyte; retrodunal depressions; vegetation; invasive species; Velika plaža; Montenegro

Received January 22, 2017.

Revised November 28, 2017.

Accepted December 28, 2017.

\begin{abstract}
Background and purpose: For a fairly long period, Velika plaža in Ulcinj, Montenegro has been considered to be one of the best-preserved sites with psammophilous vegetation along the Adriatic coast. In recent years, however, this area has been significantly transformed as a result of various human disturbances (e.g., a non-sustainable approach to touristic development, illegal dumping, sand exploitation etc.), and has become prone to alien plant invasions. We made a transect survey to assess the presence of alien species in the psammophilous communities.
\end{abstract}

Materials and methods: In order to make a survey of the present state of plant life on Velika plaža, its floristic composition and zonation of plant communities, 20 transects were set perpendicular to the coast, regularly every $500 \mathrm{~m}$. Quadrats $(2 \times 2 \mathrm{~m})$ were laid contiguously in the form of a belt transect starting from the area with the first colonizing plants towards the end of the sand dune system with forest vegetation. This resulted in a matrix of 1124 plots and 196 species (15 alien and 181 native), on which multivariate analysis was performed.

Results: Nine plant communities were detected, arranged in zonation from sea to inland. All of them were characterised by the presence of alien species. The least affected was the plant community dominated by Cladium mariscus, while the most affected ones were dominated by Scirpoides holoschoenus and Tripidium ravennae. Psammophilous vegetation is less affected by alien species than wetland communities. Foredunes are dominated by Xanthium orientale ssp. italicum, while Oenothera species are predominant on stable dunes.

Conclusions: Sand dunes are a highly invaded ecosystem, with changed plant communities, so conservation measures should be considered.

\section{INTRODUCTION}

Sand dunes are dynamic ecosystems located at the border between the sea and the mainland (1). Such specific and highly dynamic environments, governed by three interacting factors: waves, tides and sand particle size, are inhabited by a biota with a high degree of specialization $(2,3)$. Although psammophilous vegetation is known to be highly resistant to natural disturbances, it has been shown to be very sensitive to human-mediated disturbances, such as recreational seashore activities, beach cleaning, nourishment and restoration, pollution, exploitation for fisheries, biological invasions, coastal development and engineering, mining and climate change (4-9). 
Invasive alien species cause various problems for the invaded natural ecosystems. Together with habitat fragmentation, they are considered a major threat to native biodiversity (10). They change native plant communities and have a strong ecological impact on resident species, although the impact is heterogeneous and not unidirectional (11). The broadly accepted connection between invasive species and native diversity decline has recently been debated. The native species richness of dune vegetation, as well as shrublands and abandoned fields, shows a significant decline, in contrast to an insignificant decline for forest habitats (12). In addition to a reduction of local plant diversity, invasive species increase plant production of the invaded community. Some invaders, such as Carpobrotus edulis, affect the community composition, diversity and succession via modification of the soil properties. It has been shown that the effect of $C$. edulis on $\mathrm{pH}$ and nitrogen compounds persists over time even after Carpobrotus removal $(13,14)$. This suggests a possible allelopathic effect of its litter (14). Clonal growth has recently been indicated as an attribute that could contribute to the invasiveness of plants $(15,16)$. In addition to alterations in native species abundance (17), and a reduction of fitness and growth of resident plant species (18), alien species can sometimes even outcompete native species (19). The impact can further be observed on mesofauna and ground beetle communities (20), with a significant decrease in animal species fitness and abundance, as well as on microbial activity (18). The susceptibility of a plant community to invasion depends on the characteristics of the community and the life history traits of the potential invasive species (21).

Sand dunes are extreme ecosystems, with very strong gradients, which are responsible for the zonation of vegetation types. This fact, and constant disturbances (natural and anthropogenic), make sand dunes a good object for the study of alien invasion and a rich body of literature has recently become available (22-28). Sand dunes are one of the most invaded habitats (29) but different habitats along a steep gradient are invaded differently (30).

Although the coastal dunes on Velika plaža in Ulcinj are frequently cited as one of the best preserved psammophilous ecosystems in the eastern Adriatic $(31,32)$, various anthropogenic disturbances have started significantly to transform the natural potential vegetation. According to spatio-temporal analysis of the major habitat types in the area, the anthropogenic impact has been increasing since 1950. In the 1950 s, neither the pine forests now typical of the western part of the beach nor the asphalt road that connects Montenegro and Albania were present, while there were only a few houses in Štoj village. In the 1970s, construction of the road started, the pine forest was planted, and Štoj settlement started to develop. In 2015, the situation was significantly different, while urbanization expanded. According to official statistics, Velika plaža in Ulcinj is one of the most popular tourist destinations in Montenegro, and interest is constantly growing.
In relation to Velika plaža, illegal dumping, nonplanned sand exploitation, urbanization and non-sustainable tourist development are recognized as serious threats to sand dune ecosystems (33). Because research of alien species has not been systematically done in the area, invasive alien species have not been listed as a threat.

We wanted to answer the following questions:

- Which alien plant species occur on the sand dunes of Velika plaža?

- Which plant communities/habitats are more frequently invaded?

\section{METHODS}

\section{Study area}

The study was performed on coastal sand dunes on Velika plaža in Ulcinj (Montenegro). With a length of 12 $\mathrm{km}$, this sandy beach is considered to be the longest on the eastern Adriatic coast. Together with its hinterland, it covers an area of 1,270 ha. According to the KöppenGeiger system, the climate is classified as Csa type - Mediterranean climate with hot summers (34). Psammophilous vegetation forms two distinct belts: the one closer to the sea is represented by four xerohalophilous plant communities, and the second belt, which is not directly influenced by seawater, comprises xeropsammophilous communities of Mediterranean pastures and dry meadows (for details see Šilc, et al. (35)). The site is very valuable from a nature conservation point of view because the following NATURA 2000 habitats are present: 1210 Annual vegetation of drift lines, 1410 Mediterranean salt meadows (Juncetalia maritimi), 2110 Embryonic shifting dunes, 2120 Shifting dunes along the shoreline with Ammophila arenaria (white dunes), 2190 Humid dune slacks, 2220 Dunes with Euphorbia terracina, 2240 Brachypodietalia dune grasslands with annuals, 2270* Wooded dunes with Pinus pinea and/or Pinus pinaster, 3170* Mediterranean temporary ponds, and 92A0 Salix alba and Populus alba galleries (36). Under national legislation, the site was already legally protected as a natural object in 1968 (37), in 2007 as a natural monument (38), while the installation of fences in 2014 provided an additional conservation measure (39). Montenegro is currently in progress of inventorying Natura 2000 sites, but no management plans have so far been adopted.

\section{Vegetation sampling}

To analyse the floristic composition, particularly the presence of alien species and the zonation of plant communities, 20 transects were set perpendicular to the coast, exactly $500 \mathrm{~m}$ distant from each other. Contiguous quadrats $(2 \times 2 \mathrm{~m})$ were laid out next to each other to form a belt transect (40) starting from the area, with the first colonizing plants, towards the end of the sand dune sys- 

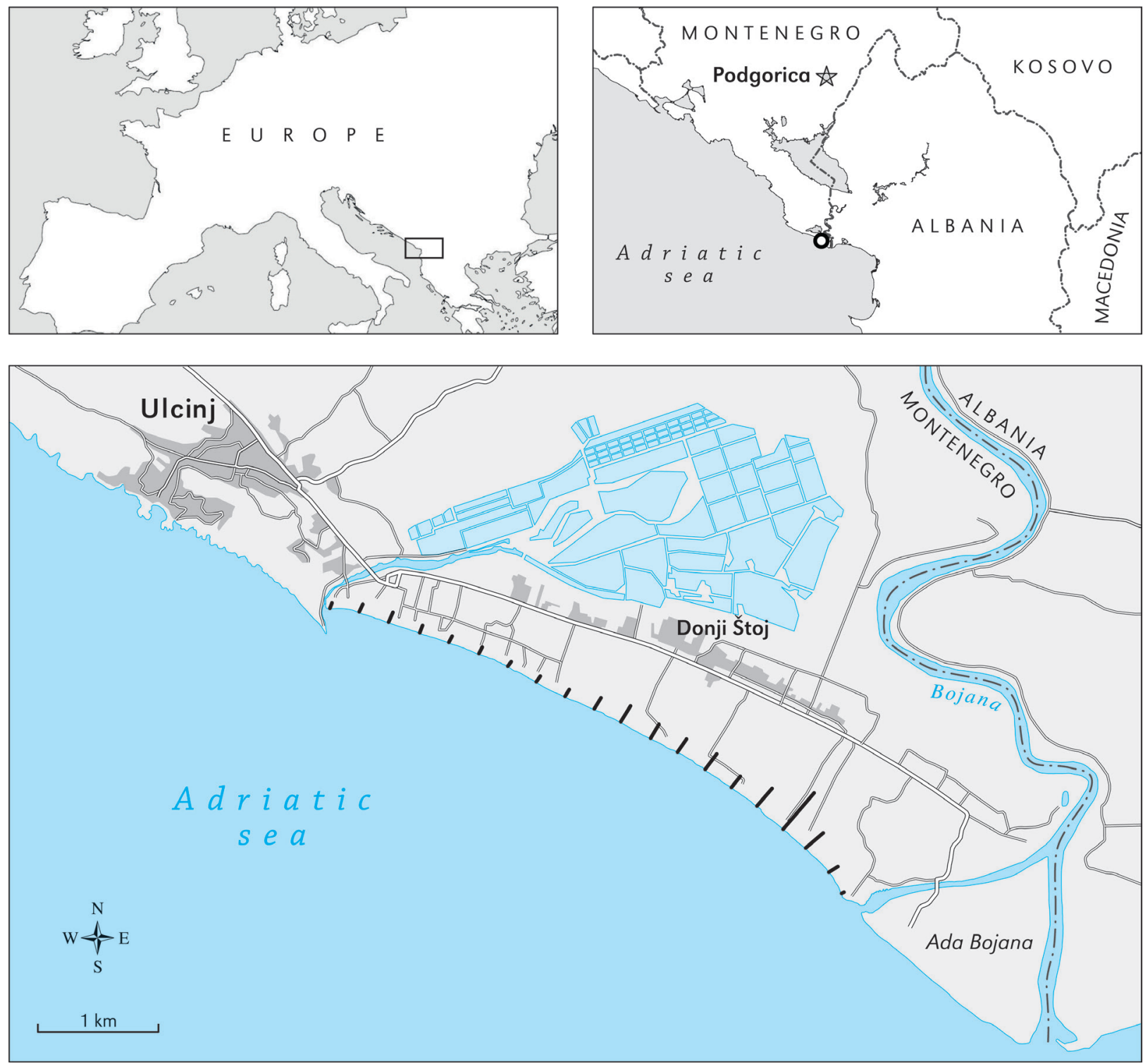

Figure 1. Location of the studied Velika plaža (Montenegro).

tem, with forest vegetation. We also analysed plant communities of interdunal depressions and humid slacks, which are often overlooked in similar studies. For the longest transects, which had large homogeneous areas of singular plant communities, the quadrats were placed 20 $\mathrm{m}$ apart from each other along the transect (and not contiguously). In each quadrat, the cover of plant species was visually estimated on the Braun-Blanquet scale (41). Since transects were performed in the late spring and early summer of 2015, when Erigeron canadensis L., E. sumatrensis Retz. and Oenothera species are just starting to germinate, it was not possible to identify this species. Identification was therefore left at the genus level. For the area, the following Oenothera taxa were reported: $O . \times$ fallax Renner, O. glazioviana Micheli, O. biennis L., and O. suaveolens Pers. ((42-44) and own field observations).

\section{Data analysis}

All gathered plots were entered into the TURBOVEG database (45). The result was a matrix of 1124 plots (876 with species present) and 196 species on which multivariate analyses were performed. Classification (Ward method and Euclidean distance) was made in PC-ORD (46), using Braun-Blanquet cover values after changing them into percentages and square-root transformation. Clusters were identified by their diagnostic species using the JUICE program (47). Diagnostic species were determined using the phi-coefficient as a fidelity measure (48). The size of all groups was standardized to equal size and Fisher's exact test $(\mathrm{p}<0.1)$ was applied.

The cumulative species pool was calculated as the total number of species, native and alien, in a particular plant 
Table 1. Frequency of alien plant species (neophytes) in sand dune plant communities on Velika plaža (Montenegro). Different grey colours indicate three classes of alien taxa frequency in the plots: light grey (0-24\%), dark grey (25-49\%), black (50-100\%). Sign + indicates the presence of alien species outside the surveyed transects.

\begin{tabular}{|c|c|c|c|c|c|c|c|c|c|c|}
\hline & $\begin{array}{l}\text { Annual } \\
\text { vegetation of } \\
\text { a drift line }\end{array}$ & & $\begin{array}{c}\text { Embry- } \\
\text { onic shifting } \\
\text { dunes }\end{array}$ & $\begin{array}{c}\text { Shifting } \\
\text { dunes along } \\
\text { the shoreline } \\
\text { with } \\
\text { Ammophila } \\
\text { arenaria }\end{array}$ & $\begin{array}{l}\text { Fixed coastal } \\
\text { dunes with } \\
\text { herbaceous } \\
\text { vegetation }\end{array}$ & $\begin{array}{c}\text { Humid dune } \\
\text { slack }\end{array}$ & & & $\begin{array}{c}\text { Mediter- } \\
\text { ranean salt } \\
\text { meadows } \\
\text { (Juncetalia } \\
\text { maritimae) }\end{array}$ & \\
\hline & 1210 & & 2110 & 2120 & $2130^{*}$ & 2190 & & & 1410 & \\
\hline & $\begin{array}{c}\text { Cakilo- } \\
\text { Xanthietum } \\
\text { strumarii }\end{array}$ & $\begin{array}{l}\text { Cynodon } \\
\text { dactylon } \\
\text { community }\end{array}$ & $\begin{array}{c}\text { Euphorbio } \\
\text { paraliae- } \\
\text { Agropyretum } \\
\text { junceiformis }\end{array}$ & $\begin{array}{c}\text { Medicagini } \\
\text { marinae- } \\
\text { Ammophile- } \\
\text { tum australis }\end{array}$ & $\begin{array}{l}\text { Onobrychis } \\
\text { caput-galli } \\
\text { community }\end{array}$ & $\begin{array}{l}\text { Schoeno- } \\
\text { Erianthetum } \\
\text { ravennae }\end{array}$ & $\begin{array}{l}\text { Holoschoene- } \\
\text { tum romani }\end{array}$ & $\begin{array}{l}\text { Cladietum } \\
\text { marisci }\end{array}$ & $\begin{array}{l}\text { Juncetum } \\
\text { maritimo- } \\
\text { acuti }\end{array}$ & $\begin{array}{l}\text { Road } \\
\text { verges }\end{array}$ \\
\hline Amorpha fruticosa & 1 & & 1 & 12 & & 20 & & 36 & 53 & \\
\hline Bidens frondosus & 3 & & & & & & 30 & & 12 & \\
\hline Capsicum annuиm & & & & & 1 & & & & & \\
\hline Carpobrotus edulis & & & 1 & & & & & & & \\
\hline $\begin{array}{l}\text { Conyza spp. (C. canadensis, } \\
\text { C.albida) }\end{array}$ & & 25 & 2 & & 20 & 23 & 7 & & & \\
\hline Cuscuta caestiana & & & & & & & 3 & & & \\
\hline Erigeron annuus & & & & & 1 & & & & & \\
\hline Euphorbia maculata & & 8 & & & & & 17 & & 4 & \\
\hline $\begin{array}{l}\text { Oenothera spp. (O. fallax, } \\
\text { O. glazoviana, O. biennis, } \\
\text { O. suaveolens) }\end{array}$ & 1 & 29 & 35 & 59 & 66 & 79 & 27 & & 14 & \\
\hline Paspalum paspalodes & & & & & & 2 & 3 & & & \\
\hline Paspalum dilatatum & & & & & & 2 & 3 & & & \\
\hline $\begin{array}{l}\text { Xanthium orientale ssp. } \\
\text { italicum }\end{array}$ & 72 & 65 & 24 & 41 & 3 & 5 & 67 & & 10 & \\
\hline Amaranthus chlorostachys & & & & & & & & & & + \\
\hline Amaranthus retroflexus & & & & & & & & & & + \\
\hline Aster squamatus & & & & + & + & & & & & \\
\hline Cenchrus spinifex & + & + & & & & & & & & \\
\hline Datura inoxia & & & & & & & & & & + \\
\hline Physalis angulata & & & & & & & & & & + \\
\hline Robinia pseudacacia & & & & & & & & & + & + \\
\hline Sporobolus indicus & & + & & & & & & & & + \\
\hline Tagetes minuta & & & & & & & & & & + \\
\hline
\end{tabular}

community. The level of invasion was set as the proportion of alien species in the community compared to its cumulative species pool $(24,49)$.

We consider a plot 'invaded' if it contains at least one alien species. The effect of the factor community on the frequency of invasion (defined as the number of plots invaded in each community) was evaluated through a chisquare test by contingency table (50).

Since sand dunes are very extreme habitats, plant species cover is a better indicator of environmental conditions, so we analysed changes of cover of alien species between plant communities in the coastal zonation (23). For each plot, we calculated total alien and native species cover (transformed from the Braun-Blanquet scale) in JUICE (47). To test differences of alien cover between plant communities, we used one-way analysis of variance (ANOVA). The Bonferroni post-hoc test was used when differences were statistically significant.
All univariate statistics were performed using the statistical package SPSS (51).

\section{Nomenclature}

The nomenclature of species follows the Euro+Med list (52), while the nomenclature of the genus Oenothera follows Rostański (53), and for Cuscuta and Carpobrotus species the Plant List was used (54). The invasive status of alien species in Montenegro was determined according to Stešević \& Petrović $(42,43)$. In this paper, we used only neophytes as alien species, defined as species with arrival/ first occurrence after the year 1500 (55).

\section{RESULTS}

The classification of vegetation plots revealed nine plant communities, which we could further classify into six dune habitats according to the Habitats Directive 
Table 2. Total species number and number of alien taxa in the different communities surveyed.

\begin{tabular}{|c|c|c|c|c|c|c|c|c|c|}
\hline Habitat & & Plant community & 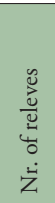 & $\begin{array}{l}\bar{\vdots} \\
\vdots \\
\tilde{y} \\
\stackrel{\mathscr{u}}{u} \\
\text { के }\end{array}$ & $\begin{array}{l}\stackrel{\mathscr{u}}{0} \\
\tilde{\Xi} \\
\text { के } \\
\frac{0}{\pi} \\
\frac{0}{4}\end{array}$ & 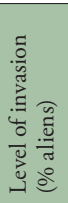 & 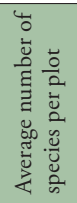 & 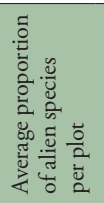 & 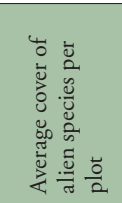 \\
\hline \multirow[t]{2}{*}{ Annual vegetation of a drift line } & 1210 & $\begin{array}{l}\text { Cakilo-Xanthietum strumarii (Beg. 1941) } \\
\text { Pignatti } 1958\end{array}$ & 371 & 62 & 4 & 0.06 & 3.42 & 0.77 & $1.97 \pm 2.41$ \\
\hline & & Cynodon dactylon community & 52 & 64 & 4 & 0.06 & 9.52 & 1.27 & $3.73 \pm 3.61$ \\
\hline Embryonic shifting dunes & 2110 & $\begin{array}{l}\text { Euphorbio paraliae-Agropyretum junceiformis } \\
\text { Tüxen in Br.Bl. \& Tüxen } 1952 \text { corr. Darimont, } \\
\text { Duvigneaud \& Lambdon } 1962\end{array}$ & 192 & 67 & 5 & 0.07 & 8.90 & 0.63 & $2.15 \pm 3.93$ \\
\hline $\begin{array}{l}\text { Shifting dunes along the shoreline } \\
\text { with Ammophila arenaria }\end{array}$ & 2120 & $\begin{array}{l}\text { Medicagini marinae-Ammophiletum australis } \\
\text { Br.-B1. } 1921 \text { corr. F.Prieto \& T.E. Díaz } 1991\end{array}$ & 17 & 24 & 3 & 0.13 & 7.53 & 1.12 & $5.66 \pm 5.39$ \\
\hline $\begin{array}{l}\text { Fixed coastal dunes with } \\
\text { herbaceous vegetation }\end{array}$ & $2130^{*}$ & Onobrychis caput-galli community & 86 & 75 & 5 & 0.07 & 15.52 & 0.91 & $5.07 \pm 5.20$ \\
\hline \multirow[t]{3}{*}{ Humid dune slack } & 2190 & Schoeno-Erianthetum ravennae Pignatti 1953 & 66 & 128 & 6 & 0.05 & 19.03 & 1.29 & $4.71 \pm 4.60$ \\
\hline & & Holoschoenetum romani Tchou 1948 & 30 & 73 & 8 & 0.11 & 10.37 & 1.57 & $3.85 \pm 1.66$ \\
\hline & & Cladietum marisci Allorge 1921 & 11 & 33 & 1 & 0.03 & 9.09 & 0.36 & $2.73 \pm 4.90$ \\
\hline $\begin{array}{l}\text { Mediterranean salt meadows } \\
\text { (Juncetalia maritimae) }\end{array}$ & 1410 & Juncetum maritimo-acuti Horvatić 1934 & 51 & 92 & 5 & 0.05 & 16.43 & 0.92 & $7.32 \pm 10.37$ \\
\hline
\end{tabular}

(Table 1). We use phytocoenological syntaxa for the description of plant communities but translation into habitat types enables comparison on a European scale.

These habitat types represent typical sand dune zonation of plant communities from sea to mainland. These are: aphytic beach; annual vegetation Cakilo-Xanthietum strumarii; its degraded community with Cynodon dactylon; embryonic sand dunes with Euphorbio paraliae-Agro- pyretum junceiformis; mobile dunes with Medicagini marinae-Ammophiletum australis; fixed dunes dominated by Onobrychis caput-galli community; mosaic of wetland associations Schoeno-Erianthetum ravennae, Holoschoenetum romani, Cladietum marisci; and salt meadows dominated by Juncus species (Juncetum maritimo-acuti).

Altogether, we found 15 alien species in the surveyed vegetation plots, representing $7.65 \%$ of all observed plant

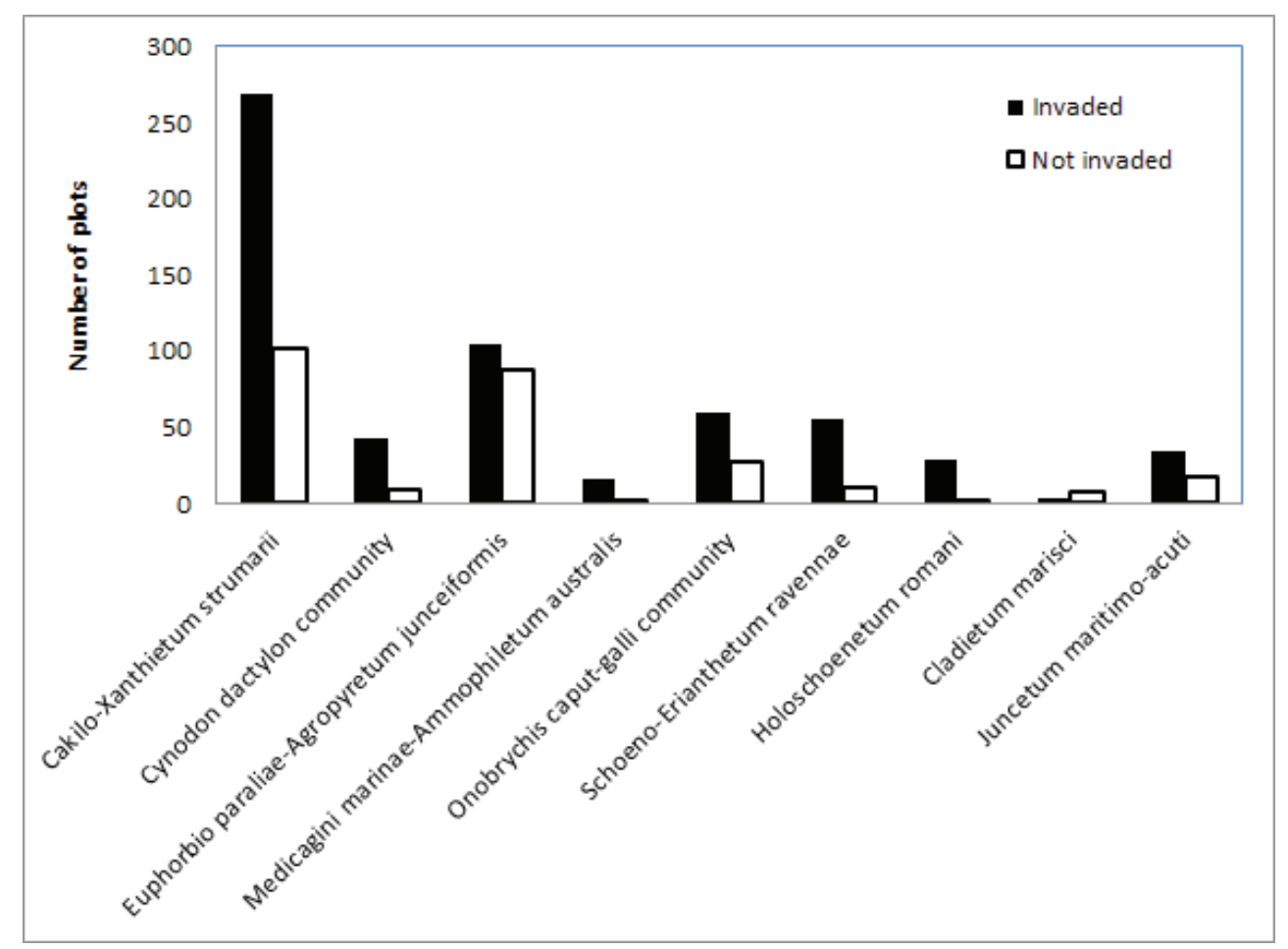

Figure 2. Invasion frequency (number of invaded and not invaded plots) for each surveyed community $\left(\chi^{2}=53.688, d f=8, p<0.001\right)$. 
species, while a further 10 species were observed in the study area outside recorded plots, mostly along roads (Table 1). Roads and pathways are an integral component of the beach system, particularly the touristic part. At least one alien species was found in each plant community, but communities differed in alien species presence, which ranged from only one species (Cladietum marisci) to a maximum of eight species (Holoshoenetum romani). Both extremes were observed in wetland communities (Table 1).

In the area under examination, Amorpha fruticosa, Oenothera spp. and Xanthium orientale ssp. italicum were shown to have an invasion frequency that exceeded 50\% per plant community (Table 1). Amorpha fruticosa had such a high frequency in only one plant community (Juncetum maritimo-acuti), while Xanthium and Oenothera spp. were highly frequent in 3 different plant communities each.

The level of invasion was highest in mobile dunes with Medicagini marinae-Ammophiletum australis, and in the Holoschoenetum romani wetland community (Table 2). There was also the highest number of alien species in the latter. The highest cover of neophytes was found in Juncus dominated stands (Juncetum maritimo-acuti), particularly because of the invading deciduous shrub Amorpha fruticosa. The lowest level of invasion (0.03\%) was reported for Cladietum marisci, with only one alien species.

Analysis of differential invasion showed a pattern of different occurrence of alien species in sand dune habitats. Almost half of embryonic sand dunes and Juncus dominated communities were invaded by at least one alien species (Fig. 2). Two-thirds of dune depressions with Cladium mariscus were invaded by neophytes but only Amorpha fruticosa was present (Table 1).

\section{DISCUSSION}

Our analysis revealed that alien plant species occur in plant communities to different extents along the zonation on sand dunes and have different impacts on species composition.

\section{Low number of aliens}

The number of alien species reported in most studies of sand dunes is modest, although it can vary from 8 to 26 (even 50) (23-26, 56). It depends also on the methodology used; some studies mention only species found in vegetation plots $(23,57)$, while others also report the results of floristic surveys $(25,28)$. Nevertheless, the number is low, and differences are present mostly in the cover

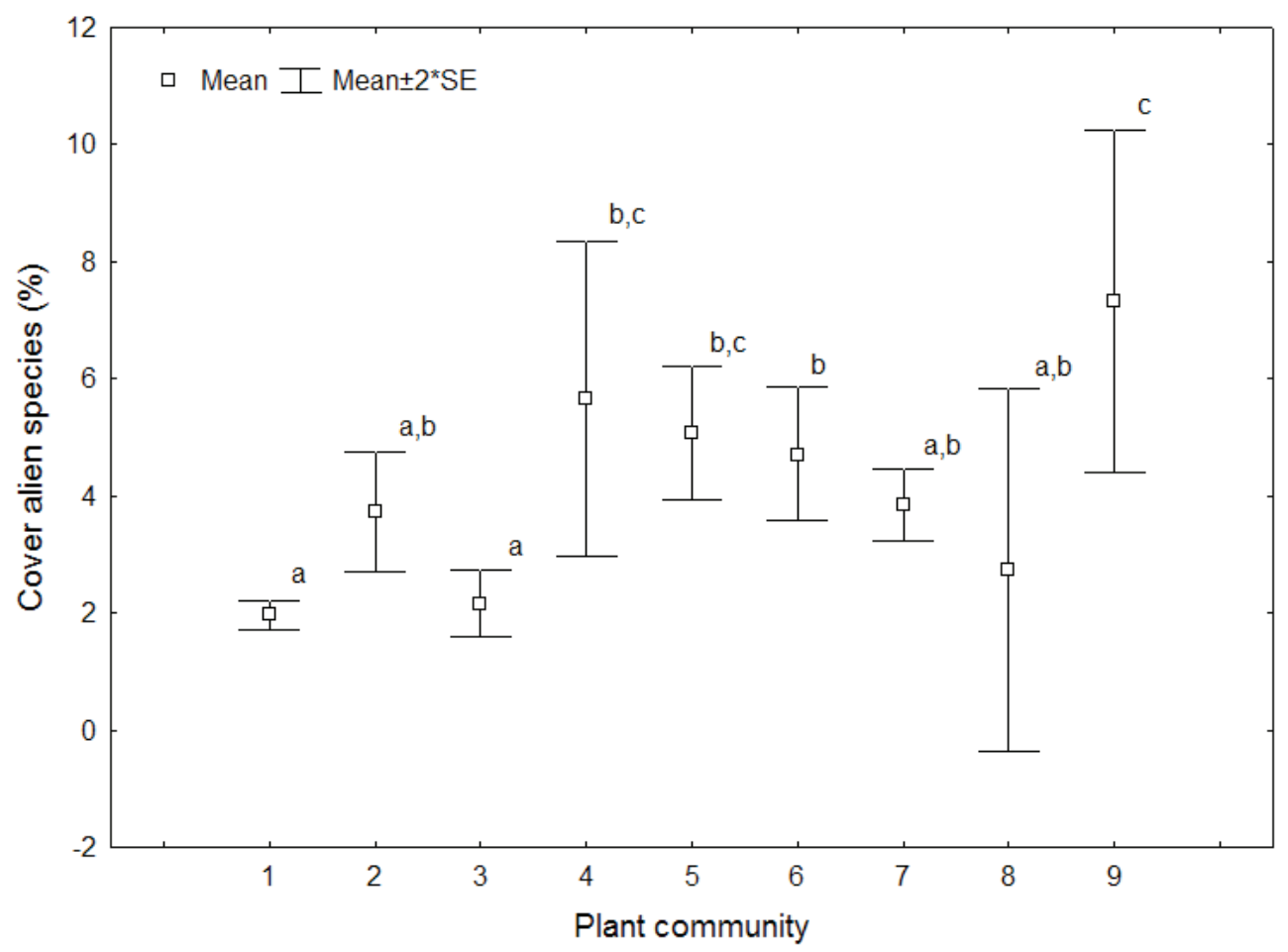

Figure 3. Cover of alien plant species in different plant communities (ANOVA: $F=15.11, P<0.001, d f=8$ ). Letters represent statistically significant differences according to the Bonferoni post-hoc test at $p<0.05$. 1 Cakilo-Xanthietum strumarii, 2 Cynodon dactylon community, 3 Euphorbio paraliae-Agropyretum junceiformis, 4 Medicagini marinae-Ammophiletum australis, 5 Onobrychis caput-galli community, 6 Schoeno-Erianthetum ravennae, 7 Holoschoenetum romani, 8 Cladietum marisci, 9 Juncetum maritimo-acuti. 
and frequency of species. Some alien species (e.g., Agave, Acacia, Carpobrotus edulis), stand out with high cover on sand dunes and can alter the structure and physiognomy of plant communities $(58,59)$. In our study area, Amorpha fruticosa may be such a transformer species in wetland communities. Amorpha is one of the worst alien species in Europe (60). It occurs mainly in wetlands and is considered to be a transformer species $(61,62)$. It is known to change the species composition and succession of invaded communities (63). Although Amorpha is not reported from neighbouring sand dune regions as an invasive species (23), it is common on embankments of riparian forests in Albania (64). We can predict its spread in sand dune humid slacks and wetlands, since it is already a serious problem in other habitats in the Balkans (65-68).

Another problem is that invading species with different life forms compared to the majority of the native species present cause structural changes in these communities (69). Amorpha fruticosa is a shrub species invading a herbaceous community, and this can lead to successional changes. Similar changes of saltmarshes due to invasion of the shrub Baccharis halimifolia have been reported from Spain (70).

\section{Affected plant communities}

Sand dune habitats differ in their level of invasion, and similar habitats are also differently invaded in different climates $(29,49)$. It is characteristic of sand dunes that general climatic factors are less important for species composition than local micro-environmental factors $(71,72)$.

Coastal dunes are characterized by zonation of habitats, in which environmental factors change (73). There may be several reasons for differently invaded habitats on sand dunes. Coastal dunes are susceptible to plant invasions due to the low number of species, the existence of micro-sites open to their establishment and a low level of competition (74). It should be mentioned that both human disturbance and environmental stress affect alien invasions in coastal dune communities (57).

The environmental gradient along sea-inland is very harsh, with wind, waves, tides, salinity, sand grain size, and dune morphology all having an impact (75). As human disturbance, direct physical disturbance of the site (trampling, beach cleaning etc.) can be considered, but strong propagule pressure is thought to be among the most important reasons for alien invasions of plant communities (23). However, there is no general rule about the different rate of susceptibility of sand dune habitats to invasion, at least not in Europe, although it is known that there are strong community differences in the factors governing invasibility (76).

Nevertheless, it has been shown that in Atlantic dunes (NE Europe), shrub and woody communities are more invaded $(26,28)$. Shrubs are also the predominant aliens in these dunes; Rosa rugosa in particular is known as an invader of dunes in northern Europe (77, 78), such as (e.g., Hippophae rhamnoides) in Ireland (20). It must be stressed, though, that native shrubs that do not belong to these environments are also invading northern dunes (79). A different pattern is observed in the Mediterranean, where herbaceous sand dune plant communities are most invaded. In some cases, mobile dunes of the Ammophiletea class $(28,57)$, or transitional dunes of the Crucianelletalia maritimae order (23), are reported to be the most invaded communities. There are contradictory reports of climax vegetation being very invaded (28), or macchia at the end of sand dune zonation, with the least number of aliens species (57). On Velika plaža, shrub vegetation was never present at the distant end of the sand dunes from the sea, and zonation ends with wetland or riparian vegetation (80). A similar situation is found in the neighbouring beach of Velipoje in Albania (81). Further south in Albania, shrub communities are present in sand dune zonation but with few alien species (64).

Also within the wider coastal zonation outside strict psammophilous vegetation, different levels of invasion can be observed. Sand dunes have an intermediate position in terms of the number of alien taxa present, since saltmarshes and cliffs have few alien species (25) and woody communities are usually more invaded $(26,28)$. Humid slacks behind sand dunes also have a high number of neophytes (Table 2) and they are invaded by ruderal species or species from other vegetation types $(25,73)$. Invasive species can form monospecific communities that represent a serious conservation problem. In our case, Oenothera spp. can dominate in shifting and fixed dunes and Amorpha fruticosa in wetlands.

Humid dune slacks are important parts of a dune system, decreasing the aeolian withdrawal rate of sand due to increasing humidity and vegetation cover (82) and their floristic and structural composition should be preserved.

Successful invasive species have different characteristics and traits (83). They can thrive in the same habitat as in their native range, but they can also be from other habitats (e.g., ruderals, weeds). Species not originally from sand dunes are more successful in stabilized habitats and slacks, where they find adequate conditions for their successful establishment and reproduction (73). Oenothera spp. are originally ornamental species that prefer open habitats with light, sandy or gravelly, frequently disturbed soils (84), with a ruderal strategy (25). This is congruent with our findings, in which Oenothera spp. occur on more shifting dunes and more fixed dunes with anthropogeneous impact.

It is possible that some stochastic invasion effects, such as initial population size, residence time and number of introduction attempts (85), are responsible for the invasion of sand dunes and this may also be the reason for different patterns of invaded communities along the sand dune zonation in various regions.

We already know that new species are constantly invading sand dune communities and that changes in veg- 
etation composition occur over time (24). Neophytes first arrived in the Cakile maritima community but a few decades later, mobile and fixed dunes are most invaded (24). As the number of archeophytes may be a good predictor of neophyte invasion risk (29), it is foreseen that sand dune communities rich in archaeophytes will suffer further invasion. The presence of neophytes also facilitates the establishment of other neophytes and alien species (17). Neophytes are useful (and often deliberately used) for the stabilisation of dunes (86) and, as already mentioned, such habitats are again more ready for new invasions (87).

\section{Conservation}

Invasion of alien species has been recognized as a major problem for conservation management, and its control should be integrated into habitat restoration (77). In addition to ecological effects, invasive species also bring huge economic costs. A conservative estimate of costs of biological invasions is at least 12.7 billion euro annually (88).

There is an extensive literature to date on control of invasive alien species, including mechanical, chemical and biological methods, but for dynamic habitats such as sand dunes, uprooting and subsoil burial have been suggested as a good combination of methods (89). A study by Kollmann, et al. (77) showed that mechanical control of Rosa rugosa by uprooting and burial of plants could not fully prevent re-sprouting of root fragments. Burial needs to be combined with hand pulling over several years, as suggested by Pickart, et al. (89) for Lupinus arboreus, However, the negative aspect of the burial method is that it destroys the original dune structure (77), as well as that it might lead to an increase of mineralization (90).

Studies of ecological success and vegetation response after removal of the invasive Carpobrotus hybrid complex concluded that removal reduced Carpobrotus density to a great extent $(91,92)$. However, successful control will require repeated hand-pulling treatments. Treated plots had a significant increase in species richness, especially annual plants, compared to invaded plots, but both had the same native plant cover and diversity. A similar species composition was found between plots subject to removal and non-invaded plots, indicating that revegetation is not necessary. Long-term monitoring is necessary to determine whether these observed patterns of community response are transient or stable through succession.

A recent study by Novoa, et al. (59) suggests that the presence of $C$. edulis litter, which causes changes in soil properties and microbial communities on coastal dune ecosystems, promotes the success of ruderal opportunistic species and constrains the establishment of native dune species (e.g., Malcolmia littorea). To restore dune ecosystems invaded by $C$. edulis successfully, it is therefore crucial to (i) remove not only living parts of the invasive species, but also litter, (ii) overseed the restored area with appropriate native dune species, and (iii) follow up to remove opportunistic ruderal species that are likely to constrain the establishment of the sown species, and colonization by other typical dune species.

Although the dunes are recognized as endangered ecosystems in Montenegro, control of invasive species to date has not been integrated into management or restoration plans. Only trampling exclusion zones have so far been installed on Velika plaža (39). At least for shifting and fixed dunes on Velika plaža, removal of the most common alien Oenothera should be performed. Another important action would be education of beach managers to prevent the planting of alien ornamental plants. Carpobrotus edulis has already been planted but has not yet spread.

Suggestions for the improvement and protection of the landscape (93) are also applicable for Velika plaža and could be achieved by eradication of non-native flora, exclusion of parts of the beach from intensive use (building, dumping, high number of visitors), and the development of sustainable forms of tourism.

\section{Acknowledgements}

We thank Filip Küzmič for comments on the final version and Iztok Sajko for producing the map. Martin Cregeen kindly checked our English. The research was partly financed by ARRS through research program (P10236), Rufford Grant 14048-1 and bilateral project (BIME/16-17-018).

\section{REFERENCES}

1. MCLACHLAN A, BROWN A C 2006 The ecology of sandy shores. Academic Press, New York, p 373

2. MCLACHLAN A 2001 Coastal beach ecosystems. In: LEWIN R (ed) Encyclopedia of Biodiversity. Academic Press, New York, p 741-751. https://doi.org/10.1016/B0-12-226865-2/00051-1

3. WIEDEMANN A M, PICKART A J 2004 Temperate zone coastal dunes. In: MARTÍNEZ M L and PSUTY N P (ed) Coastal dunes ecology and conservation. Springer Berlin p53-65

4. ANDERSEN U V 1995 Resistance of Danish Coastal Vegetation Types to Human Trampling. Biological Conservation 71: 223-230. https://doi.org/10.1016/0006-3207(94)00031-K

5. CICCARELLI D 2014 Mediterranean Coastal Sand Dune Vegetation: Influence of Natural and Anthropogenic Factors. Environmental Management 54: 194-204.

https://doi.org/10.1007/s00267-014-0290-2

6. DEFEO O, MCLACHLAN A, SCHOEMAN D S, SCHLACHER T A, DUGAN J, JONES A, LASTRA M, SCAPINI F 2009 Threats to sandy beach ecosystems: A review. Estuarine Coastal and Shelf Science 81: 1-12

7. GARCIA-MORA M R, GELLEGO-FERNANDEZ J B, GARCIA-NOVO F 1999 Plant functional types in coastal foredunes in relation to environmental stress and disturbance. Journal of Vegetation Science 10: 27-34

8. SALAFSKY N, SALZER D, STATTERSFIELD A J, HILTONTAYLOR C, NEUGARTEN R, BUTCHART S H, COLLEN B, COX N, MASTER L L, O'CONNOR S, WILKIE D 2008 A 
standard lexicon for biodiversity conservation: unified classifications of threats and actions. Conservation Biology 22: 897-911

9. ŠILC U, DAJIĆ STEVANOVIĆ Z, IBRALIU A, LUKOVIĆ M, STEŠEVIĆ D 2016 Human impact on sandy beach vegetation along the southeastern Adriatic coast. Biologia 71: 865-874. https://doi.org/10.1515/biolog-2016-0111

10. COUNCIL OF EUROPE 2007 The Bern Convention (Convention on the conservation of European wildlife and natural habitats, Bern, 1979). Question and Answers, No. 9

11. VILÀ M, ESPINAR J L, HEJDA M, HULME P E, JAROŠIK V, MARON J L, PERGL J, SCHAFFNER U, SUN Y, PYŠEK P 2011 Ecological impacts of invasive alien plants: a meta-analysis of their effects on species, communities and ecosystems. Ecology Letters 14: 702-708

12. GAERTNER M, DEN BREEYEN A, HUI C, RICHARDSON D M 2009 Impact of alien plant invasion on species richness in Mediterranean-type ecosystems: a meta analysis. Progress in Physical Geography 33: 319-338.

https://doi.org/10.1177/0309133309341607

13. CONSER C, CONNOR E F 2008 Assessing the residual effects of Carpobrotus edulis invasion, implications for restoration. Biological Invasions 11: 349-358.

https://doi.org/10.1007/s10530-008-9252-z

14. NOVOA A, GONZÁLEZ L, MORAVCOVÁ L, PYŠEK P 2012 Effects of Soil Characteristics, Allelopathy and Frugivory on Establishment of the Invasive Plant Carpobrotus edulis and a CoOccuring Native, Malcolmia littorea. PLOS ONE 7: e53166. https://doi.org/10.1371/journal.pone.0053166

15. LECHUGA-LAGO Y, SIXTO-RUIZ M, ROILOA S R, GONZÁLEZ L 2016 Clonal integration facilitates the colonization of drought environments by plant invaders. AoB PLANTS plw023

16. SONG Y B, YU F H, KESER L H, DAWSON W, FISCHER M, DONG M, VAN KLEUNEN M 2013 United we stand, divided we fall: a meta-analysis of experiments on clonal integration and its relationship to invasiveness. Oecologia 171: 317-327

17. ISERMANN M 2008 Classification and habitat characteristics of plant communities invaded by the non-native Rosa rugosa Thunb. in NW Europe. Phytocoenologia 38: 133-150. https://doi.org/10.1127/0340-269X/2008/0038-0133

18. VILA M, ESPINAR J L, HEJDA M, HULME P E, JAROŠÍK V, MARON J L, PERGL J, SCHAFFNER U, SUN Y, PYŠEK P 2011 Ecological impacts of invasive alien plants: a meta-analysis of their effects on species, communities and ecosystems. Ecology Letters 14: 702-708

19. JUCKER T, CARBONI M, ACOSTA A T A 2013 Going beyond taxonomic diversity: deconstructing biodiversity patterns reveals the true cost of iceplant invasion. Diversity and Distributions 19: 1566-1577. https://doi.org/10.1111/ddi.12124

20. BINGGELI P, EAKIN M, MACFADYEN A, POWER J, MCCONNEL J 1992 Impact of the alien sea buckthorn (Hippophae rhamnoides $\mathrm{L}$.) on sand dune ecosystems in Ireland. In: CARTER R W G, CURTIS T G F and SHEEHY-SKEFFINGTON M J (ed) Coastal dunes; geomorphology, ecology and management for conservation. Balkema, Rotterdam, p 325-337

21. EWEL J 1986 Invasibility: Lessons from South Florida. In: MOONEY H and DRAKE J (ed) Ecology of Biological Invasions of North America and Hawaii. Springer-Verlag, New York, p 214230. https://doi.org/10.1007/978-1-4612-4988-7_13

22. ACOSTA A, ERCOLE S, STANISCI A, BLASI C 2006 Sandy coastal ecosystems and effects of disturbance in central Italy. Journal of Coastal Research SI39: 985-989

23. CARBONI M, SANTORO R, ACOSTA A T R 2010 Are some communities of the coastal dune zonation more susceptible to alien plant invasion? Journal of Plant Ecology 3: 139-147. https://doi.org/10.1093/jpe/rtp037

24. DEL VECCHIO S, PIZZO L, BUFFA G 2015 The response of plant community diversity to alien invasion: evidence from a sand dune time series. Biodiversity and Conservation 24: 371-392. https://doi.org/10.1007/s10531-014-0814-3

25. CAMPOS J A, HERRERA M, BIURRUN I, LOIDI J 2004 The role of alien plants in the natural coastal vegetation in centralnorthern Spain. Biodiversity \& Conservation 13: 2275-2293

26. WEEDA E J 2010 The role of archaeophytes and neophytes in the Dutch coastal dunes. Journal of Coastal Conservation 14: 75-79. https://doi.org/10.1007/s11852-009-0079-2

27. GALLO A G, DE LA TORRE W W, RODRÍGUEZ V M 2008 Especies vegetales consideradas invasoras de hábitats, en la Historia Natural de Canarias. Lazaroa 29: 49-67

28. ASENSI A, DÍEZ-GARRETAS B, PEREÑA J 2016 Alien plants of coastal dune habitats in southern Spain. Plant Biosystems-An International Journal Dealing with all Aspects of Plant Biology 150: $477-483$

29. CHYTRÝ M, MASKELL L C, PINO J, PYŠEK P, VILÀ M, FONT X, SMART S M 2008 Habitat invasions by alien plants: a quantitative comparison among Mediterranean, subcontinental and oceanic regions of Europe. Journal of Applied Ecology 45: 448-458

30. CARRANZA M L, RICOTTA C, CARBONI M, ACOSTA A T R 2011 Habitat selection by invasive alien plants. A bootstrap approach. Preslia 83: 529-536

31. STEŠEVIĆ D, BUBANJA N, CAKOVIĆ D, JOGAN N, LUKOVIĆ M, ŠILC U 2017 Synecology of Cutandia maritima (L.) Barbey, a rare psammophytic species along the Montenegrin Coast (East Adriatic Coast). Hacquetia 16: 181-187. https://doi.org/10.1515/hacq-2017-0002

32. MIJOVIĆA, POPOVIĆZ, VUKOVT, SMILJANIĆM, MATIĆ R, BOJOVIĆ S 2012 Sand topography influences the distribution of xerohalophytic vegetation on a southern Adriatic beach in Montenegro. Plant Biosystems 146: 664-673. https://doi.org/10.1080/11263504.2012.687403

33. PETROVIĆ D, KARAMAN M 2009 Important plant areas in Montenegro - IPA Programme. NVO Zelena Gora, Podgorica, p 79

34. BURIĆ D, DUCIĆ V, MIHAJLOVIĆ J 2014 The climate of Montenegro: Modificators and types- part two. Bulletin of the Serbian geographical society 9: 73-90

35. ŠILC U, MULLAJ A, ALEGRO A, IBRALIU A, DAJIĆ STEVANOVIĆ Z, LUKOVIĆ M, STEŠEVIĆ D 2016 Sand dune vegetation along the eastern Adriatic coast. Phytocoenologia 46: 339-355. https://doi.org/10.1127/phyto/2016/0079

36. PETROVIĆ D, HADŽIABLAHOVIĆ S, VUKSANOVIĆ S, MAČIĆ V, LAKUŠIĆ D 2012 Katalog tipova staništa Crne Gore značajnih za Evropsku uniju. Podgorica-Beograd-Zagreb, p 116

37. OFFICIAL GAZETTE SRCG 1968

38. OFFICIAL GAZETTE OF MONTENEGRO 2007

39. ŠILC U, CAKOVIĆ D, KÜZMIČ F, STEŠEVIĆ D 2017 Trampling impact on vegetation of embryonic and stabilised sand dunes in Montenegro. Journal of Coastal Conservation 21: 15-21. https://doi.org/10.1007/s11852-016-0468-2

40. KENT M 2012 Vegetation Description and Data Analysis: A Practical Approach Wiley-Blackwell, Chichester, p 414

41. BRAUN-BLANQUET J 1964 Pflanzensoziologie. Grundzüge der Vegetationskunde. Springer Verlag, Wien, p 865. https://doi.org/10.1007/978-3-7091-8110-2

42. STEŠEVIĆ D, CAKOVIĆ D 2013 Contribution to the alien flora of Montenegro and Supplementum to the Preliminary list of plant invaders. Biologica Nyssana 4: 1-7 
43. STEŠEVIĆ D, PETROVIĆ D 2010 Preliminary list of plant invaders in Montenegro. Biologica Nyssana 1: 35-42

44. RAKAJ M, ROSTANSKI K 2009 New species of the genus Oenothera L. from coasts of the Albania and Montenegro. Natura montenergrina 8: 163-171

45. HENNEKENS S M, SCHAMINÉE J H J 2001 TURBOVEG, a comprehensive data base management system for vegetation data. Journal of Vegetation Science 12: 589-591. https://doi.org/10.2307/3237010

46. MCCUNE B, GRACE J B 2002 Analysis of ecological communities. MjM Software Design, Glenden Beach, p 300

47. TICHÝ L 2002 JUICE, software for vegetation classification. Journal of Vegetation Science 13: 451-453. https://doi.org/10.1111/j.1654-1103.2002.tb02069.x

48. CHYTRÝ M, TICHÝ L, HOLT J, BOTTA-DUKAT Z 2002 Determination of diagnostic species with statistical fidelity measures. Journal of Vegetation Science 13: 79-90. https://doi.org/10.1111/j.1654-1103.2002.tb02025.x

49. CHYTRÝ M, PYŠEK P, TICHÝ L, KNOLLOVÁ I, DANIHELKA J 2005 Invasions by alien plants in the Czech Republic: a quantitative assessment across habitats. Preslia 77: 339-354

50. ROHLF F J, SOKAL R R 1995 Statistical Tables. Freeman, New York, p 199

51. IBM CORP. 2013 IBM SPSS Statistics for Windows, Version 22.0. IBM Corp., Armonk, NY

52. EURO+MED 2006- Euro+Med PlantBase - the information resource for Euro-Mediterranean plant diversity. http://ww2.bgbm. org/EuroPlusMed

53. ROSTAŃSKI K 2010 Evening-Primroses (Oenothera) occuring in Europe. W. Szafer Institute of Botany, Polish Academy of Sciences, Katowice-Kraków, p

54. THE PLANT LIST 2013 The Plant List. http://www.theplantlist.org/

55. PYŠEK P, RICHARDSON D M, REJMANEK M, WEBSTER G L, WILLIAMSON M, KIRSCHNER J 2004 Alien plants in checklists and floras: towards better communication between taxonomists and ecologists. Taxon 53: 131-143

56. MARCANTONIO M, ROCCHINI D, OTTAVIANI G 2014 Impact of alien species on dune systems: a multifaceted approach. Biodiversity and Conservation 23: 2645-2668. https://doi.org/10.1007/s10531-014-0742-2

57. ACOSTA A, CARRANZA M L, IZZI C F 2008 Community types and alien species distribution in Italian coastal dunes. Neobiota 7: 96-104

58. RICHARDSON D M, PYŠEK P, REJMÁNEK M, BARBOUR M G, PANETTA F D, WEST C J 2000 Naturalization and invasion of alien plants: concepts and definitions. Diversity and distributions 6: 93-107

59. NOVOA A, GONZÁLEZ L, MORAVCOVÁ L, PYŠEK P 2013 Constraints to native plant species establishment in coastal dune communities invaded by Carpobrotus edulis: Implications for restoration. Biological Conservation 164: 1-9.

https://doi.org/10.1016/j.biocon.2013.04.008

60. DAISIE E 2009 Handbook of alien species in Europe. Springer, Berlin, p 399

61. KOZUHAROVA E, MATKOWSKI A, WOŹNIAK D, SIMEONOVA R, NAYCHOV Z, MALAINER C, MOCAN A, NABAVI S M, ATANASOV A G 2017 Amorpha fruticosa - A Noxious Invasive Alien Plant in Europe or a Medicinal Plant against Metabolic Disease? Frontiers in Pharmacology 8: 1-17. https://doi.org/10.3389/fphar.2017.00333

62. TÖRÖK K, BOTTA-DUKÁT Z, DANCZA I, NÉMETH I, KISS J, MIHÁLY B, MAGYAR D 2003 Invasion gateways and corridors in the Carpathian Basin: biological invasions in Hun- gary. Biological Invasions 5: 349-356.

https://doi.org/10.1023/B:BINV.0000005570.19429.73

63. WALTER J, ESSL F, ENGLISCH T, KIEHN M 2005 Neophytes in Austria: habitat preferences and ecological effects. Neobiota 6: $13-25$

64. IMERI A, MULLAJ A, DODONA E, KUPE L 2010 Costal vegetation of the Lalzi bay (Albania). Botanica serbica 34: 99-105

65. PEDASHENKO H P, APOSTOLOVA I I, VASSILEV K V 2012 Amorpha fruticosa invasibility of different habitats in lower Danube. Phytologia Balcanica 18: 285-291

66. BORŠIĆ I, MILOVIĆ M, DUJMOVIĆ I, BOGDANOVIĆ S, CIGIĆ P, REŠETNIK I, NIKOLIĆ T, MITIĆ B 2008 Preliminary check-list of invasive alien plant species (IAS) in Croatia. Natura Croatica 17: 55-71

67. TUCOVIĆ A, ISAJEV V, ŠIJAČIĆ-NIKOLIĆ 2004 Secondary range and ecophysiological characteristics of Amorpha fruticosa $\mathrm{L}$. in Serbia. Bulletin of the Faculty of Forestry, Beograd 89: 223-230

68. RADOVANOVIĆ N, KUZMANOVIĆ N, VUKOJIČIĆ S, LAKUŠIĆ D, JOVANOVIĆ S 2017 Floristic diversity, composition and invasibility of riparian habitats with Amorpha fruticosa: A case study from Belgrade (Southeast Europe). Urban Forestry \& Urban Greening 24: 101-108. https://doi.org/10.1016/j.ufug.2017.04.006

69. MARCHANTE H, MARCHANTE E, FREITAS H 2003 Invasion of the Portuguese dune ecosystems by the exotic species Acacia longifolia (Andrews) Willd.: effects at the community level. In: (ed) Plant invasions: ecological threats and management solutions. Backhuys, Leiden, The Netherlands, p 75-85

70. CAÑO L, CAMPOS J A, GARCÍA-MAGRO D, HERRERA M 2013 Replacement of estuarine communities by an exotic shrub: distribution and invasion history of Baccharis halimifolia in Europe. Biological Invasions 15: 1183-1188

71. BARBOUR M G, JOHNSON A F 1977 Beach and dune. In: BARBOUR M G and MAJOR J (ed) Terrestrial vegetation of California. Wiley and Sons, New York, p 223-261

72. CONTI L, DE BELLO F, LEPŠ J, ACOSTA A T R, CARBONI M 2017 Environmental gradients and micro-heterogeneity shape fine scale plant community assembly on coastal dunes. Journal of Vegetation Science 28: 762-773

73. CASTILLO S A, MORENO-CASASOLA P 1996 Coastal sand dune vegetation: an extreme case of species invasion. Journal of Coastal Conservation 2: 13-22

74. JØRGENSEN R H, KOLLMANN J 2009 Invasion of coastal dunes by the alien shrub Rosa rugosa is associated with roads, tracks and houses. Flora - Morphology, Distribution, Functional Ecology of Plants 204: 289-297

75. ACOSTA A, ERCOLE S, STANISCI A, PILLAR V D, BLASI C 2007 Coastal vegetation zonation and dune morphology in some Mediterranean ecosystems. Journal of Coastal Research 23: 15181524

76. D'ANTONIO C M 1993 Mechanisms controlling invasion of coastal plant communities by the alien succulent Carpobrotus edulis. Ecology 74: 83-95. https://doi.org/10.2307/1939503

77. KOLLMANN J, JØRGENSEN R H, ROELSGAARD J, SKOVPETERSEN H 2009 Establishment and clonal spread of the alien shrub Rosa rugosa in coastal dunes-a method for reconstructing and predicting invasion patterns. Landscape and Urban Planning 93: 194-200

78. HOUSTON J 2008 Management of Natura 2000 habitats. 2130 *Fixed coastal dunes with herbaceous vegetation („grey dunes") European Commission, $\mathrm{p}$

79. ISERMANN M, DIEKMANN M, HEEMANN S 2007 Effects of the Expansion by Hippophaë rhamnoides on Plant Species Richness in Coastal Dunes. Applied Vegetation Science 10: 33-42. https://doi.org/10.1111/j.1654-109X.2007.tb00501.x 
80. ŠILC U, STEŠEVIĆ D, ROZMAN A, CAKOVIĆ D and KÜZMIČ F 2018 Alien species and their impact on sand dunes in NE Adriatic. In: FINKL C W and MAKOWSKI C (ed) Impacts of Invasive Species on Coastal Environments: Coasts in Crisis. Springer (in print)

81. FANELLI G, DE SANCTIS M, GJETA E, MULLAJ A, ATTORE F 2015 The vegetation of the Buna river protected landscape (Albania). Hacquetia 14: 129-174. https://doi.org/10.1515/hacq2015-0008

82. GARCÍA-MORA M R, GALLEGO-FERNÁNDEZ J B, WILLIAMS A T, GARCIA-NOVO F 2001 A coastal dune vulnerability classification. A case study of the SW Iberian Peninsula. Journal of coastal research 17: 802-811

83. ACOSTA A, IZZI C F, STANISCI A 2006 Comparison of native and alien plant traits in Mediterranean coastal dunes. Community ecology 7: 35-41

84. MIHULKA S, PYŠEK P 2001 Invasion History of Oenothera Congeners in Europe: A Comparative Study of Spreading Rates in the Last 200 Years. Journal of Biogeography 28: 597-609. https://doi. org/10.1046/j.1365-2699.2001.00574.x

85. REJMANEK M 2000 Invasive plants: approaches and predictions. Austral ecology 25: 497-506.

https://doi.org/10.1046/j.1442-9993.2000.01080.x

86. KUTIEL P, COHEN O, SHOSHANY M, SHUB M 2004 Vegetation establishment on the southern Israeli coastal sand dunes between the years 1965 and 1999. Landscape and Urban Planning 67: 141-156. https://doi.org/10.1016/S0169-2046(03)00035-5

87. VALLES S M, CAMBROLLE J 2013 Coastal Dune Hazards. In: FINKL C (ed) Coastal Hazards. Springer, p 491-510

88. KETTUNEN M, GENOVESI P, GOLLASCH S, PAGAD S, STARFINGER U 2009 Technical support to EU strategy on invasive alien species (IAS) assessment of the impacts of IAS in Europe and the EU. IEEP, Brussels

89. PICKART A J, THESIS K C, STAUFFER H B, OLSEN G T 1998 Yellow bush lupine invasion in northern California coastal dunes: II. Mechanical restoration techniques. Restoration Ecology 6: 69-74. https://doi.org/10.1046/j.1526-100x.1998.00619.x

90. DASSONVILLE N, VANDERHOEVEN S, VANPARYS V, HAYEZ M, GRUBER W, MEERTS P 2008 Impacts of alien invasive plants on soil nutrients are correlated with initial site conditions in NW Europe. Oecologia 157: 131-140. https://doi.org/10.1007/s00442-008-1054-6

91. ANDREU J, MANZANO-PIEDRAS E, BARTOMEUS I, DANA.D.E., VILÀ M 2010 Vegetation Response after Removal of the Invasive Carpobrotus Hybrid Complex in Andalucía, Spain. Ecological Restoration 28: 440-448

92. ANDREU J, VILÀ M 2007 Análisis de la gestión de las plantas exóticas en los espacios naturales espańoles. Ecosistemas 3: 1-16

93. ZIMMITTI A, MANGIAFICO R, PITRUZZELLO P 2015 Requalification of coastal plant landscape of South-Eastern Sicily, Italy: the case of Marina di Priolo. Biodiversity Journal 6: 165-170 